International Journal of Instruction e-ISSN: 1308-1470 • www.e-iji.net

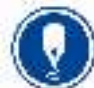

July $2021 \bullet$ Vol.14, No.3

p-ISSN: 1694-609X

pp. 1011-1024

Article submission code

20201103122450

Received: 03/11/2020

Revision: 11/02/2021
Accepted: 07/03/2021

OnlineFirst: 24/06/2021

\title{
Students 'satisfaction with Using E-Learning to Learn Chemistry in Light of the COVID-19 Pandemic in Jordanian Universities
}

\section{Tarik Faris Al Soub}

Dr., Aqaba University of Technology, Jordan,Tsoub@aut.edu.jo

Raghad Shaher Alsarayreh

Dr., Al-Balqa Applied University, Karak College, Jordan, Ragad.Sarayreh@bau.edu.jo

\section{Nidal Zaki Amarin}

Dr., Al-Zaytoonah University of Jordan, Jordan, Nidal.a@ zuj.edu.jo

University Education in Jordan has adapted completely to Distance Education due to the corona virus (COVID-19) pandemic. The study aimed to assess students' satisfaction with distance education of chemistry courses during the COVID-19 pandemic at Aqaba University of Technology (AUT). The students' satisfaction was assessed by a survey consisting of 4 items as follows: interaction with elearning, techniques, instruction, and website improvement. The statistical analyses have been done using descriptive and interferential analytical approaches by the Statistical Package for Social Sciences. The results indicated that students 'satisfaction with using e-learning to learn chemistry in light of the COVID-19 pandemic at AUT was high. The interaction with e-learning and techniques reflected a high level of satisfaction while instruction and website improvement reflected a medium level of satisfaction. There was a significant difference $(\alpha \leq 0.05)$ in students' satisfaction in terms of gender. Females were more significantly satisfied with the four items and overall satisfaction.

Keywords: e-learning, chemistry learning, corona pandemic, student's satisfaction, Covid-19

\section{INTRODUCTION}

E-learning has been started before the year 2000 in different forms as blended learning and distance education. The use of E-learning applications such as Moodle and Blackboard has been recently increased. Furthermore, the video interaction applications such as Zoom meeting, Google classes, and Microsoft teams now were used in education.

In light of the corona virus (COVID-19) pandemic, there is a lot of movement restrictions and lockdown. Jordan has applied many constrictions to prevent the spread of COVID-19. There was a series of partial and complete lockdown. Therefore, 
University education has been completely turned into distance education since March 2020. This turning into distance education required rapid and specific interventions. The students' dissatisfaction with distance learning was expected due to many reasons. First, the digital gap between students according to their geographic regions (Yulia, 2020). Second, the need to modernize traditional learning methods requires a lot of preparation in a short time. Finally, the readiness of teachers and students toward distance education was suboptimal and the difficulties in communications (Zaharah \& Kirilova, 2020). Therefore, the application of e-learning is not always smooth and effective, during the COVID-19 outbreak universities have implemented e-learning quickly.

Satisfaction has been defined as " a function of the perceived and expected performance of the student " (Kotler, 2001). If the performance is less than expected, the student will be lack pleasure or resentment. In the case where performance exceeds what is expected by the student, it turns from satisfaction into loyalty to the organization and will be closely related to it (Kotler, 2001).

Teaching scientific courses, especially chemistry, using e-learning needs designing the material to suit the style of distance teaching (Nguyen \& Klein, 2008). Interactive learning style is required and the teachers play the co-learners and acts as facilitators (Zhang, 2005). The online material may include video discussion, assignments, home works, and quizzes and solutions. These technological facilities may improve students' interaction and participation. On another hand, the learning environment satisfaction was associated with a social presence, which has a significant effect on the educational process. Hence, the study aim was to assess the students' satisfaction with the distance education of chemistry courses during the COVID-19 pandemic at Aqaba University of Technology (AUT) in Jordan. Webb \& Moallem (2016) and Zimbardi et al (2017) showed the effect of students' use of feedback on the subsequent performance of education. The study results could be used as feedback to improve distance education.

\section{Literature review}

Oranburg (2020) showed five steps to teaching online that should be followed by faculty members who urgently need to make the transition from in-class to teaching online competently and they are:

1. For teaching materials it must be specified whether they are "synchronous" (life) or "asynchronous" (recorded).

- When the teacher has already developed teaching materials and activities in the classroom, simultaneous teaching over the Internet is like teaching in the classroom.

- Synchronous remote virtual classrooms work well for small groups, but as class size increases to over 20 students, classroom discussion and other dynamics collapse, so teachers of larger classes who choose to teach simultaneously may need to use modern and discreet pedagogical strategies.

- Asynchronous education requires skill in video production and editing plus time and effort. It is best suited for creative faculty members and those who teach large subjects frequently. 
- Asynchronous preparation helps the teacher reuse it many times, and this preparation itself is easier if the teacher already has some recorded material that can be used.

- $\quad$ Synchronous learning provides more direction and structure to students while asynchronous learning is preferred by busy students and self-directed learners because it allows them to learn on their schedules.

2. Acquiring the hardware and software necessary to create effective online content.

- Visual Get a good webcam and stand if you plan to host virtual classrooms.

- Programs available to you via your institution's subscriptions.

- Knowing the programs on the computer, especially PowerPoint, which is the easiest tool for recording effective video clips.

- Explore enrolment options in your classroom; If your organization has a studio for recording green screen or light.

3. If it is not synchronized, your video content is created:

- $\quad$ Divide subject topics into more precise (smaller) units that can be streamed in 5 to 10 minutes of video.

- Design PowerPoint slides easily and clearly, using graphics, pictures, and a specified number of words in each slide.

- $\quad$ You can write verbatim text if you are concerned about making errors.

- Determine which platform of software you will use (Zoom meeting, GoToMeeting, Moodle, etc.), set up an account, schedule virtual class meetings, and learn how to use the features.

4. Develop your online learning environment.

- Use your enterprise platform.

- $\quad$ Organize your content first by week, then by lesson.

- Upload your video content and educational material to a media server, whether that is the media platform licensed by your organization or YouTube.

5. Publish your attachment to the class.

- $\quad$ Provide opportunities for student feedback.

- $\quad$ Use advertising tools to keep everyone informed.

- $\quad$ Respond to concerns and solve problems quickly.

- Keep your cool and carry on.

Ibrahem et al (2017) assessed student satisfaction and barriers to an e-learning course among nursing students at Mansoura University, and the results showed that the majority of students who were studied are very satisfied with their e-learning experience. In agreement, Cole et al (2014) found an acceptable level of satisfaction that was not differed by gender, age, or level of study. 
Students rated their online instruction as moderately satisfactory, with hybrid or partial online materials rated as moderately more satisfactory than entirely online course materials. "Comfort" was the most frequently mentioned reason for satisfaction. "Lack of interaction" was the most cited cause of dissatisfaction.

Several studies have assessed different forms of E-learning. Lockma \& Schirm (2020) reviewed the research literature on online learning to identify effective teaching practices and performed an analysis of 104 research studies. Studies identified five topics of students' satisfaction as course design factors, student support, faculty, student participation, and student success factors.

Some studies have focused on direct comparisons between the effectiveness of distance, blended, and face-to-face learning (Carbone, 2018; Harris \& Nikitenko, 2014; Jovanovic et al., 2015; Ryan et al., 2016; Xu \& Jaggars, 2014). The results consistently showed that there were no statistically significant differences in student learning between educational methods.

\section{METHOD}

\section{Research questions}

1- Are students satisfied with using Distance education for chemistry in light of the COVID-19 pandemic at AUT?

2- Are there statistically significant differences in terms of gender variables?

\section{The methodology of the study}

The methodology used in this study depends on the descriptive and analytical approach that includes a desk survey by referring to the references and sources to build the theoretical framework of the study, and a field survey to collect data using the study tool and analyze it statistically to answer the study questions.

\section{Study population and sample}

The study population consists of (126) students. The study sample consisted of (52) students; 30 females who were registered in General Chemistry (1) course at the academic year (2019/2020).

\section{The instrument of the Study}

A questionnaire was developed to measure students 'satisfaction with using e-learning to teach chemistry in light of the COVID-19 pandemic in AUT. The questionnaire is in the Appendix. The questionnaire includes the students' satisfaction with the following variables: Interaction with e-learning, instructions, techniques, and website improvement. Each item has a five-point Likert scale as: Strongly Satisfied (5 points), Satisfied (4 points), Neutral (3 points), Dissatisfied (2 points), and Very Dissatisfied (1 point)

Accordingly, if the arithmetic means value for the paragraphs is greater than (3.67-5), then the level of perceptions is high, but if the arithmetic means value ranges between 
(2.33-3.66) the level of perceptions are Medium, and if the arithmetic mean is less than (2.33), then the level of perceptions is low. Depending on the criterion of upper limit lower limit.

\section{The validity of the instrument of the study}

To verify the validity of the paragraphs of the questionnaire, the study tool was presented to several referees, including professors of educational administration and faculty members in Jordanian universities. They were asked to revise and review the paragraphs of the questionnaire in terms of the clarity of the paragraphs and the quality of their linguistic formulation. The revisions and comments were considered.

\section{Stability of the instrument of the study}

The stability coefficient was extracted, using the (Cronbach's Alpha) formula for internal consistency, whereby the questionnaire was distributed to an exploratory sample from outside the sample. their number reached (30) members of the study community, and Table (1) shows the results of that:

Table 1

The reliability coefficient value for the internal consistency of the instrument as a whole and each dimension of the study

\begin{tabular}{lll}
\hline the tool & the field & Stability coefficient \\
\hline Students' satisfaction with using e- & Interact with e-learning & 0.87 \\
\cline { 2 - 3 } learning to teach chemistry in light of the & Instructions & 0.84 \\
\cline { 2 - 3 } Corona pandemic at Aqaba University of & Techniques & 0.86 \\
\cline { 2 - 3 } Technology & Website improvement & 0.82 \\
\hline The Total & & 0.91 \\
\hline
\end{tabular}

The results presented in Table (1) indicate that the stability coefficients ranged between $(0.82-0.87)$, while the overall stability factor was $(0.91)$. These values are considered acceptable for the study, noting that the acceptable internal consistency ratio is $(0.60$ and above).

\section{Statistical Analysis}

To treat the study statistically, the Statistical Package for Social Sciences (SPSS.22.1) program was used to process data to answer the study questions. The level of significance was set at $\alpha \leq 0.05$, according to the following statistical treatments:

1- Calculating frequencies and percentages to describe the characteristics of the study sample, and calculating the arithmetic means and standard deviations to answer the study questions.

2- Single analysis of variance, and a translucent test for statistically significant variables, were used.

\section{The answer to the first question}

Are students satisfied with using the model as a teaching method for chemistry in light of the COVID-19 pandemic at AUT? 
To answer the question, the mediums and standard deviations were calculated for each paragraph in each domain and the overall domains and compared with question medium (Stander value).

\section{The answer to the second question}

Are there statistically significant differences in terms of gender variable?

To answer this question, a Single analysis of variance was used to compare the response between males and females at each item and overall score.

\section{FINDINGS}

The students show a high level of overall satisfaction. Specifically, interact with elearning (3.98 \pm 0.6$)$ and techniques $(3.88 \pm 0.73)$ show a high level of satisfaction while instructions (3.62 \pm 0.76$)$ and website improvement $(3.81 \pm 0.59)$ show a medium level of satisfaction, table 2 .

Table 2

Arithmetic means and standard deviations of the aggregate domains

\begin{tabular}{lllll}
\hline Domain number & Domain name & Arithmetic mean & Standard deviation & Estimate \\
\hline 1 & Interact with e-learning & 3.98 & .600 & High \\
\hline 2 & Techniques & 3.88 & .730 & High \\
\hline 3 & Instructions & 3.62 & .700 & Medium \\
\hline 4 & Website improvement & 3.41 & .760 & Medium \\
\hline The Total & & 3.81 & 0.59 & High \\
\hline
\end{tabular}




\section{First Item: interaction with e-learning}

Table 3

Arithmetic means and standard deviations for the field of interaction with e-learning

\begin{tabular}{|c|c|c|c|c|}
\hline $\begin{array}{l}\text { Paragraph } \\
\text { number }\end{array}$ & Paragraph text & $\begin{array}{l}\text { Arithmetic } \\
\text { mean }\end{array}$ & $\begin{array}{l}\text { Standard } \\
\text { deviation }\end{array}$ & Estimate \\
\hline 1 & I have improved my skills in using the Internet. & 4.04 & .960 & High \\
\hline 2 & $\begin{array}{l}\text { The interaction with the subject teacher is adequately } \\
\text { maintained }\end{array}$ & 4.12 & .840 & High \\
\hline 3 & I can ask a question to the subject teacher at any time & 4.20 & .820 & High \\
\hline 4 & $\begin{array}{l}\text { I am satisfied with the confidentiality of the } \\
\text { information on the site }\end{array}$ & 4.11 & .890 & High \\
\hline 5 & $\begin{array}{l}\text { I am dissatisfied with the collaboration activities } \\
\text { process during the semester }\end{array}$ & 4.10 & .850 & High \\
\hline 6 & The web session always keeps me alert and focused & 4.07 & .860 & High \\
\hline 7 & $\begin{array}{l}\text { Adequate training for using the Internet was obtained } \\
\text { in this article. }\end{array}$ & 3.70 & .950 & High \\
\hline 8 & $\begin{array}{l}\text { There is continuous coordination between me and the } \\
\text { subject teacher about the points raised electronically. }\end{array}$ & 3.62 & .940 & Medium \\
\hline 9 & $\begin{array}{l}\text { I feel comfortable doing some electronic } \\
\text { correspondence for the posts on the scientific subject } \\
\text { compared to other materials. }\end{array}$ & 3.68 & .870 & High \\
\hline 10 & $\begin{array}{l}\text { The information obtained in the scientific material } \\
\text { exceeds the information that can be obtained by } \\
\text { traditional educational methods. }\end{array}$ & 3.78 & .830 & High \\
\hline 11 & $\begin{array}{l}\text { Using the site in this class encourages me to learn } \\
\text { independently. }\end{array}$ & 4.03 & .810 & High \\
\hline 12 & $\begin{array}{l}\text { My understanding is improved compared to similar } \\
\text { subjects that I have studied before using traditional } \\
\text { teaching. }\end{array}$ & 3.93 & .780 & High \\
\hline 13 & $\begin{array}{l}\text { My performance on the tests has improved compared } \\
\text { to similar previous classes I've taken before. }\end{array}$ & 4.12 & .780 & High \\
\hline 14 & $\begin{array}{l}\text { I am satisfied with the level of effort required in this } \\
\text { class }\end{array}$ & 4.14 & .790 & High \\
\hline 15 & I am not satisfied with my performance in this season & 4.07 & .870 & High \\
\hline 16 & $\begin{array}{l}\text { I think I will be satisfied with my final degree in the } \\
\text { subject. }\end{array}$ & 4.00 & .880 & High \\
\hline 17 & $\begin{array}{l}\text { I am satisfied that I have been able to apply what I } \\
\text { have learned in this material. }\end{array}$ & 4.02 & .870 & High \\
\hline The Total & & 3.98 & .600 & High \\
\hline
\end{tabular}

Table (3) shows that the paragraph (There is continuous coordination between me and the subject teacher about the points presented electronically) had the lowest grade (3.62). The rest of the paragraphs were highly rated and that the highest rating was for the paragraph (I can ask a question to the subject teacher at any time possible) and the mean value of it was (4.20). 


\section{Second Item: instructions}

Table 4

Arithmetic means and standard deviations of the field of instructions

\begin{tabular}{lllll}
\hline $\begin{array}{l}\text { Paragraph } \\
\text { number }\end{array}$ & Paragraph text & $\begin{array}{l}\text { Arithmetic } \\
\text { mean }\end{array}$ & $\begin{array}{l}\text { Standard } \\
\text { deviation }\end{array}$ & Estimate \\
\hline 18 & $\begin{array}{l}\text { At the beginning of each chapter, there are } \\
\text { instructions on the materials offered }\end{array}$ & 3.67 & .950 & High \\
\hline 19 & $\begin{array}{l}\text { Using the site in this material encourages me to } \\
\text { learn independently. }\end{array}$ & 3.86 & .950 & High \\
\hline 20 & $\begin{array}{l}\text { Sufficient information has been provided to use } \\
\text { the Chemistry website. }\end{array}$ & 3.69 & .910 & High \\
\hline 21 & $\begin{array}{l}\text { Sending and receiving educational materials } \\
\text { electronically was unimpeded. }\end{array}$ & 3.40 & .930 & Medium \\
\hline 22 & Instructions are found on the site & 3.63 & .970 & Medium \\
\hline 23 & The instructions are available to everyone & 3.49 & 1.02 & Medium \\
\hline 24 & $\begin{array}{l}\text { The handling of the site is comfortable and } \\
\text { simplified }\end{array}$ & 3.58 & .940 & Medium \\
\hline & The Total & 3.62 & .700 & Medium \\
\hline
\end{tabular}

Table (4) shows that the paragraph (I am encouraged by the use of the site in this subject to learn independently) had the highest estimate and the medium value for it was (3.86). The (18-20) paragraphs were high and the rest of the paragraphs were rated medium and the lowest was for the paragraph (sending and receiving educational materials electronically was without any obstacles) and the mean value of it was (3.40).

\section{Third Items: Techniques}

Table 5

Arithmetic means and standard deviations for the field of techniques

\begin{tabular}{lllll}
\hline $\begin{array}{l}\text { Paragraph } \\
\text { number }\end{array}$ & Paragraph text & $\begin{array}{l}\text { Arithmetic } \\
\text { mean }\end{array}$ & $\begin{array}{l}\text { Standard } \\
\text { deviation }\end{array}$ & Estimate \\
\hline 25 & Information on the site can be easily shared & 3.95 & .850 & High \\
\hline 26 & $\begin{array}{l}\text { Major obstacles are preventing us from accessing } \\
\text { instructions }\end{array}$ & 3.89 & .890 & High \\
\hline 27 & Instructions can be added on the site as needed & 3.92 & .830 & High \\
\hline 28 & $\begin{array}{l}\text { Confidentiality in the information on the site related } \\
\text { to the material }\end{array}$ & 3.86 & .870 & High \\
\hline 29 & $\begin{array}{l}\text { There is adequate technical assistance to facilitate the } \\
\text { use of technological means in the scientific material. }\end{array}$ & 3.96 & .860 & High \\
\hline 30 & $\begin{array}{l}\text { The teacher's voice is heard. } \\
\text { The content of the article presented on the site is clear }\end{array}$ & 3.79 & 1.00 & High \\
\hline 32 & $\begin{array}{l}\text { Video images are always clear } \\
\text { Technical problems are not frequent and do not } \\
\text { adversely affect my understanding of the material. }\end{array}$ & 3.75 & .960 & High \\
\hline 33 & $\begin{array}{l}\text { There is a program manager who helps students in the } \\
\text { event of a specific malfunction }\end{array}$ & 3.88 & 1.05 & High \\
\hline 34 & $\begin{array}{l}\text { Internet connection speed outside the university is } \\
\text { inappropriate. }\end{array}$ & 3.99 & 0.90 & High \\
\hline 35 & $\begin{array}{l}\text { The site allows the participation of all students at the } \\
\text { same time }\end{array}$ & 3.85 & .930 & High \\
\hline 36 & The Total & 3.88 & .730 & High \\
\hline
\end{tabular}


Table (5) shows that the paragraph (Internet connection speed outside the university is not appropriate) had the highest rating and its arithmetic mean value was (3.99). All the paragraphs were rated high and the lowest was for the paragraph (technical problems are not frequent and do not negatively affect my understanding of the material) and the average value of it was (3.75).

\section{Fourth Item: Website improvement}

Table 6

Arithmetic means and standard deviations of the site improvement field

\begin{tabular}{llllc}
\hline $\begin{array}{l}\text { Paragraph } \\
\text { number }\end{array}$ & Paragraph text & $\begin{array}{l}\text { Arithmetic } \\
\text { mean }\end{array}$ & $\begin{array}{l}\text { Standard } \\
\text { deviation }\end{array}$ & Estimate \\
\hline 37 & $\begin{array}{l}\text { Communication via various messages about } \\
\text { exam dates linked to the site }\end{array}$ & 3.90 & .970 & High \\
\hline 38 & $\begin{array}{l}\text { Developing the system in terms of } \\
\text { programming and constantly updating the } \\
\text { version in line with distance learning as a } \\
\text { result of the Corona epidemic }\end{array}$ & 3.70 & .870 & High \\
\hline 39 & $\begin{array}{l}\text { Recording lectures and enabling students to } \\
\text { watch them under the supervision of the } \\
\text { college }\end{array}$ & 3.37 & .960 & Medium \\
\hline 40 & $\begin{array}{l}\text { Involving platforms, sites, and educational } \\
\text { tools within the system to help students for } \\
\text { distance education }\end{array}$ & 3.09 & 1.14 & Medium \\
\hline 41 & $\begin{array}{l}\text { Set aside specific time for meetings with } \\
\text { distance learning administrators to answer } \\
\text { their inquiries }\end{array}$ & 2.97 & 1.05 & Medium \\
\hline 42 & $\begin{array}{l}\text { Continuous training for students on the use of } \\
\text { the system }\end{array}$ & 3.48 & 1.05 & Medium \\
\hline 43 & $\begin{array}{l}\text { Providing the Internet for students at the } \\
\text { university and outside the university }\end{array}$ & 3.39 & .950 & Medium \\
\hline
\end{tabular}

Table (6) shows that the paragraph (I have a constant desire to search for the truth in my field of specialization) had the highest rating, and the two paragraphs $(37,38)$ their rating was high and the mean value for them was $(3.90,3.70)$. The rest of the paragraphs were rated medium and the lowest rating was for the paragraph (allocating a specific time for meetings with distance learning officials to respond to their inquiries) and the mean value of it was (2.97).

For the second question of the study "Are there statistically significant differences at the significance level $(\alpha \leq 0.05)$ in students' satisfaction with using electronic education to teach chemistry in light of the COVID-19 pandemic at AUT due to the gender variable?"

The arithmetic mean and standard deviations were calculated for the two sex levels, and Table (7) shows the results of that. 
Table 7

Arithmetic mediums and standard deviations Students' satisfaction with using e-learning to teach chemistry in light of the COVID-19 pandemic at AUT attributable to the gender variable

\begin{tabular}{llll}
\hline the field & the level & Arithmetic mean & Standard deviation \\
\hline Interact with e-learning & Male & 3.91 & .590 \\
\cline { 2 - 4 } & female & 4.06 & .630 \\
\cline { 2 - 4 } & The Total & 3.98 & .600 \\
\hline \multirow{2}{*}{ Techniques } & Male & 3.59 & .700 \\
\cline { 2 - 4 } & female & 3.72 & .670 \\
\cline { 2 - 4 } & The Total & 3.62 & .700 \\
\hline Instructions & Male & 3.87 & .740 \\
\cline { 2 - 4 } & female & 3.96 & .680 \\
\cline { 2 - 4 } & The Total & 3.88 & .730 \\
\hline Website improvement & Male & 3.31 & .760 \\
\cline { 2 - 4 } & female & 3.52 & .750 \\
\cline { 2 - 4 } & The Total & 3.41 & .600 \\
\hline The Total & Male & 3.79 & .590 \\
\cline { 2 - 4 } & female & 3.87 & .890 \\
\cline { 2 - 4 } & The Total & 3.81 & \\
\hline
\end{tabular}

Table (7) shows that there is a difference in the values of the arithmetic media, the students' satisfaction with using e-learning to teach chemistry in light of the COVID-19 at AUT. It is attributable to a variable of gender and to find out if these differences are statistically significant, a single-multiple analysis of variance was performed, and Table (8) shows the results of that.

Table 8

An analysis of single-multiple variance of gender differences on students' satisfaction with using e-learning to teach chemistry

\begin{tabular}{lllllll}
\hline $\begin{array}{l}\text { The source of } \\
\text { the contrast }\end{array}$ & Dependent variable & $\begin{array}{l}\text { Sum of } \\
\text { squares }\end{array}$ & $\begin{array}{l}\text { Degrees of } \\
\text { freedom }\end{array}$ & $\begin{array}{l}\text { Medium } \\
\text { of squares }\end{array}$ & $\begin{array}{l}\text { Ph } \\
\text { value }\end{array}$ & $\begin{array}{l}\text { Indication } \\
\text { level }\end{array}$ \\
\hline Gender & Interact with e-learning & 3.48 & 1 & 3.48 & 8.79 & .000 \\
\cline { 2 - 7 } & Techniques & 10.03 & 1 & 10.03 & 19.85 & .000 \\
\cline { 2 - 7 } & Instructions & 7.11 & 1 & 7.11 & 12.60 & .000 \\
\cline { 2 - 7 } & Website improvement & 5.93 & 1 & 5.93 & 16.80 & .000 \\
\hline \multirow{2}{*}{ The error } & Interact with e-learning & 89.20 & 50 & 1.784 & - & - \\
\cline { 2 - 7 } & Techniques & 119.97 & 50 & 2.399 & - & - \\
\cline { 2 - 7 } & Instructions & 130.75 & 50 & 2.615 & - & - \\
\cline { 2 - 7 } & Website improvement & 143.18 & 50 & 2.863 & - & - \\
\hline \multirow{2}{*}{ The Total } & Interact with e-learning & 89.51 & 51 & - & - & - \\
\cline { 2 - 7 } & Techniques & 120.67 & 51 & - & - & - \\
\cline { 2 - 7 } & Instructions & 131.07 & 51 & - & - & - \\
\cline { 2 - 6 } & Website improvement & 143.32 & 51 & - & - & - \\
\hline
\end{tabular}

Table (8) shows that there are statistically significant differences at the significance level $(\alpha \leq 0.05)$ in students 'satisfaction with using e-learning to teach chemistry. The females show a significantly higher level of satisfaction. 


\section{DISCUSSION}

The results indicated that students 'satisfaction with using e-learning to teach chemistry in light of the COVID-19 pandemic at AUT was high (Table 2). The results indicated that there are statistically significant differences at the significance level $(\alpha \leq 0.05)$ in students' satisfaction with using e-learning to teach chemistry in light of the COVID-19 pandemic at AUT in term of gender and the four areas: interaction with e-learning, instructions, technologies, and website improvement (Table 7-8).

This result is explained by the fact that e-learning opens great horizons for students for creativity and contributes to the creation of new methods in the educational process and adding quality to the education (De Souza Rodrigues et al., 2020). Distance education may give more personal freedom and access to the educational material at any time and from anywhere and takes into account the individual differences between students and people with special needs. E-learning contributes to shortening a lot of time to accomplish the tasks of the lecturers, this enables the lecturer to benefit from his time greatly, reduce the burdens placed on the lecturers are, and the evaluation tools provided by e-learning contribute to achieving the goal of the educational process, whether students are evaluated.

E-learning also contributes to providing learners with knowledge and information about what is recent in learning different topics and helps them to eliminate barriers between specialized branches of knowledge, to provide them with different types of motivation, and provide many opportunities for creativity. It also works in helping learners to spread their ideas via the Internet and receive new ideas to enhance their learning. E-learning also contributes to developing the skills of learners by communicating between them and their teachers and the learners themselves. The students are highly satisfied with the independence of distance education. The use of modern technologies in the educational process requires them to have good and varied skills to be able to deal with this new type of education.

While concerns about the COVID-19 increase, many education leaders are taking the difficult decision to close educational institutions. To help in the transition to distance learning, distance learning has become an urgent matter required by the conditions that the whole world is going through in general and Jordan in particular (Akour et al., 2020). Jordan is at the forefront of the Arab countries that have adopted the introduction of information and communication technology in its educational system. The AUT has implemented many projects and initiatives to implement e-learning to develop and improve the teaching and learning processes. The COVID-19 crisis has made educational institutions in a state of shock and confusion made them discover the extent of their shortcomings and weaknesses in keeping pace with educational technology. Educational institutions were floundering in experimenting with educational applications to practice distance education.

This study result was in corresponding with what was stated in the study of (Ibrahem et al., 2017; Lockma \& Schirm, 2020; Webb \& Moallem, 2016) which results indicated that there is a direct effect of e-learning on students' performance. it was also incoherent 
with the study of Zimbardi et al (2017), which result showed that e-learning has the greatest impact on improvement with tasks, and students who showed high levels of interaction with feedback made the greatest improvement.

This study results can be used to inform the instructor to give more attention to the items that show a medium level of satisfaction specifically instruction and website improvement. Universities' websites now can be considered as a classroom and the main educational environment. Regular improvement of website and education instructions are highly required.

The study has some limitations. The study assesses one course. Further Studies assess the whole experience of distance learning is required to give a wider perspective about the distance education process.

\section{CONCLUSION}

The students show a high level of satisfaction about distance education in a teaching chemistry course. Further studies include assessment of all course the students learn are required to give a wide perspective for the whole experience of distance education.

\section{RECOMMENDATIONS}

The study provides some recommendations. First, spread the culture of e-learning among the faculty members and clarify its importance in the educational process by holding internal workshops. Second, the method of implementing e-learning at AUT needs significant development and reconsideration especially instructions and website improvement according to study results. Third, emphasize that the lecturers are the most critical and vital element in the success of applying e-learning. This requires the attention of training and development of the capabilities of lecturers through the establishment of centers equipped with the latest technologies to train lecturers, which leads to the creation of a university environment that contributes to creativity and innovation. Fourth, the need to pay attention to scientific seminars and conferences, and to encourage research and studies aimed at enhancing the practical aspect of e-learning, while giving their results and recommendations the importance they deserve. Finally, taking into consideration the material and moral incentives of the lecturers to make greater use of e-learning services.

\section{REFERENCES}

Akour, A., Al-Tammemi, A. B., Barakat, M., Kanj, R., Fakhouri, H. N., Malkawi, A., \& Musleh, G. (2020). The Impact of the COVID-19 Pandemic and Emergency Distance Teaching on the Psychological Status of University Teachers: A Cross-Sectional Study in Jordan. The American Journal of Tropical Medicine and Hygiene, 103(6), 23912399. https://doi.org/10.4269/ajtmh.20-0877

Carbone, D. J. (2018). Assessing Learning across Pedagogical Modalities and Learning

Retrieval Conditions for College Learners in Introductory Psychology. Community College Journal of Research and Practice, 42(5), 340-349. https://doi.org/10.1080/10668926.2017.1310066 
Cole, M. T., Shelley, D. J., \& Swartz, L. B. (2014). Online instruction, e-learning, and student satisfaction: A three-year study. International Review of Research in Open and Distance Learning, 15(6), 111-131. https://doi.org/10.19173/irrodl.v15i6.1748

de Souza Rodrigues, M. A., Chimenti, P., \& Nogueira, A. R. R. (2020). An exploration of eLearning adoption in the educational ecosystem. Education and Information Technologies, 1-31. https://doi.org/10.1007/s10639-020-10276-3

Harris, R. A., \& Nikitenko, G. O. (2014). Comparing online with brick and mortar course learning outcomes: An analysis of quantitative methods curriculum in public administration. Teaching Public Administration, 32(1), 95-107. https://doi.org/10.1177/0144739414523284

Ibrahim, A., Seada, A., \& Mostafa, M. F. (2017). Students' Satisfaction and Barriers of E-Learning Course among Nursing Students, Mansoura University. World Journal of Nursing Sciences, 3(3), 170-178. https://doi.org/10.5829/idosi.wjns.2017.170.178

Jovanovic, A., Jankovic, A., Jovanovic, S. M., Peric, V., Vitosevic, B., \& Pavlovic, M. (2015). When going hybrid is not enough: Statistical analysis of the effectiveness of blended courses piloted within Tempus BLATT Project. International Journal of Education and Development Using Information and Communication Technology, 11(2), 138-152.

http://login.ezproxy.library.ualberta.ca/login?url=http://search.ebscohost.com/login.aspx ?direct=true $\& \mathrm{db}=$ eric $\& A N=\mathrm{EJ} 1074162 \&$ site $=$ ehost-live $\&$ scope $=$ site

Kotler, P. (2001). Rinkodaros Principal (Lithuanian Translation of Principles of Marketing: 3rd European Edition) - Kent Academic Repository. https://kar.kent.ac.uk/32910/

Lockma, A. S., \& Schirm, B. R. (2020). Online instruction in higher education: Promising, research-based, and evidence-based practices. Journal of Education and ELearning Research, 7(2), 130-152. https://doi.org/10.20448/JOURNAL.509.2020.72.130.152

Nguyen, F., \& Klein, J. D. (2008). The effect of performance support and training as performance interventions. Performance Improvement Quarterly, 21(1), 95-114. https://doi.org/10.1002/piq.20017

Oranburg, S. (2020). Distance Education in the Time of Coronavirus: Quick and Easy Strategies for Professors. SSRN Electronic Journal. https://doi.org/10.2139/ssrn.3553911

Ryan, S., Kaufman, J., Greenhouse, J., She, R., \& Shi, J. (2016). The effectiveness of blended online learning courses at the community college level. Community College Journal of Research and Practice, 40(4), 285-298. https://doi.org/10.1080/10668926.2015.1044584

Webb, A., \& Moallem, M. (2016). Feedback and feed-forward for promoting problembased learning in online learning environments. Malaysian Journal of Learning and 
Instruction, 13(2), 1-41. https://doi.org/10.32890/mjli2016.13.2.1

Xu, D., \& Jaggars, S. S. (2014). Performance gaps between online and face-to-face courses: Differences across types of students and academic subject areas. Journal of Higher Education, 85(5), 633-659. https://doi.org/10.1353/jhe.2014.0028

Yulia, H. (2020). Online Learning to Prevent the Spread of Pandemic Corona Virus in Indonesia. ETERNAL (English Teaching Journal), 11(1). https://doi.org/10.26877/eternal.v11i1.6068

Zaharah, Z., \& Kirilova, G. I. (2020). Impact of Corona Virus Outbreak Towards Teaching and Learning Activities in Indonesia. SALAM: Jurnal Sosial Dan Budaya Syar-I, 7(3), 269-282. https://doi.org/10.15408/sjsbs.v7i3.15104

Zhang, D. (2005). Interactive multimedia-based E-Learning: A Study of Effectiveness. International Journal of Phytoremediation, 21(1), 149-162. https://doi.org/10.1207/s15389286ajde1903_3

Zimbardi, K., Colthorpe, K., Dekker, A., Engstrom, C., Bugarcic, A., Worthy, P., Victor, R., Chunduri, P., Lluka, L., \& Long, P. (2017). Are they using my feedback? The extent of students' feedback use has a large impact on subsequent academic performance. Assessment and Evaluation in Higher Education, 42(4), 625-644. https://doi.org/10.1080/02602938.2016.1174187 